\title{
Accounting
}

\section{Attitude formation towards Islamic banks}

\section{Osama Omar Jaara ${ }^{a}$, Abdelrahim Mohamad Kadomi ${ }^{b}$, Majda Issa Ayoub ${ }^{c}$, Nabil Ahmed Mareai Senan $^{\mathrm{d}, \mathrm{e}^{*}}$ and Bassam Omar Jaara ${ }^{\mathrm{f}}$}

\section{H R O N I C L E}

\section{Article history:} \\ Received: September 25, 2020 \\ Received in revised format: \\ September 302020 \\ Accepted: October 30, 2020 \\ Available online: \\ October 30, 2020 \\ Keywords: \\ Islamic banks concepts \\ Related theories \\ Signaling theory \\ Client's attitude \\ Religious factors \\ Non-religious factors
}

a Department of Accountancy, Faculty of Business and Finance, American University of Madaba, Jordan

${ }^{b}$ Department of Accountancy, Faculty of Business, Amman Arab University, Jordan

${ }^{c}$ Department of Marketing, Faculty of Business and Finance, American University of Madaba, Jordan

${ }^{d}$ Associate Professor, Department of Accounting, Prince Sattam Bin Abdulaziz University, Saudi Arabia

eAssociate Professor, Accounting Department, Administrative Science College, Al-Baydha University, Yemen

fFinance and Banking department. Business School, Al Ahliyya Amman university, Jordan

\section{A B S T R A C T}

This study aims to determine client's attitude explanatory factors for the selection of an Islamic bank at Jordan. Mainly, the study identifies factors shaping client's attitude toward Islamic banks that are considered in clients' decision choices related to different behavioral theories. Data were randomly collected from Islamic banks clients in Jordan. A questionnaire was developed, distributed, and analyzed via the model of t-test on 138 clients. The results show that clients consider several factors in their choices between religious and non-religious. Essentially, religious factors are principles, absence of interest, religious edict or justification, profit-sharing, and Islamic price basis of banking services. The non-religious related factors were sufficient branches, caring and comfortable, appearance and internal decoration design, fast services, response to their clients' needs, sufficient number of staff, giving clients the top priorities, clients' needs to include disclosing information as a part of accounting system adequacy. Adequate attention is needed to every client, competitive service prices, and the influence of friends and family. The study concludes that it is not possible to say that religious factors are enough, but the interest-free banking greatly represents the non-religious or the economic factors, and the profit-sharing principle is important; Policymakers must consider this to build-up a positive attitude toward Islamic banks. The findings recommend that religious and nonreligious values significantly influence clients' intentions and choices. It suggests that religious ethics is the most important factor, and the availability of information systems disclosing clients' needs.

\section{Introduction}

Banks' similarity of services and the growing competitiveness in the banking industry have become a major concern of banks today. Therefore, banks must identify differentiating factors that determine the basis of clients' choice among providers of financial services. Banks would have to pay a great deal of attention to their diverse clients' demographics, such as their religious beliefs in order to enhance clients' trust in the financial firm and encourage providing diverse options. Establishing positive clients' attitudes towards Islamic banks is the primary concern of this research paper. Clients are the most important stakeholders * Corresponding author.

E-mail address: n.senan@psau.edu.sa (N. A. M. Senan) 
in any organization; therefore, a great deal of interest should be focused on client retention and enhancing profits (N'Goala, 2007; Reichheld \& Sasser,1990). Clients have different behaviors or reactions toward business gestures (Wilson et al., 2008). Due to finance behavior theory, Islamic banks may have suffered an abusive relationship or an irrational one that reached a point of frustration especially when they provided good advice and their clients would not accept. At the same time clients may react differently toward banks business gestures (Wilson et al., 2008). Generally speaking, banks are trusted to keep clients' money safe; clients' needs ahead of the banks' objectives, transparency of fees and genuine intention to provide relevant advice. This paper's main objective is to understand the clients' rationale or attitudinal behavior on how they perceive Islamic banking. The researchers benefited from many related theories that deal with the clients' basic expectations and relationships.

\section{Literature Review}

\subsection{Islamic Banks General Concept}

Islamic banks are considered financial intermediation Institutions whose statutes, rules, and procedures explicitly state their commitment to specific principles in banning to deal with interest. At the same time, they are not holier than thou; clients have other preference factors such as family influence, quality, staff, reputation, transparency, and returns. All the latter mentioned are influential on the clients' attitudes. Different theories, such as cognitive dissonance, propose that clients can be motivated to change their attitudes, beliefs, and behaviors (Festinger \& Carlsmith, 1959). At the same time, clients with better understanding on how Islamic banks function is a suggested technique arising through sending banks messages (Yau, 1994). In building trust, banks design specific convincing communications that the services and products being sold will cover clients' unique financial and non-financial requirements (Reichheld \& Sasser, 1993). Also, some researchers suggested that banks would generate high levels of retention and profits on the costs associated with their signals as they communicate with clients or prospects (Heskett et al., 1990; Stuart et al., 2002). Additionally, Selnes (2011) adopted a specific method to understand clients' attitudes by measuring their risk level. In finance and accounting, it was possible to score a client risk-return relationship based on portfolio theory concepts (Groening et al. 2014). Since Islamic banks are established on the sharing principle, all investor clients expect to receive the highest expected returns rate from their initial investments and should always be well-prepared against possible hazard. Hamza (2016) concluded that the deposit management and profit and loss statement assets are categorized by an ethical threat behavior and unwarranted risk-taking. The estimate disclosed that capital percentage and interest rate affect directly the deposit return (Hamza, 2016). Profit and Loss sharing involves Islamic banks and clients' relationship. One appropriate investment is fixed income; however, Febianto (2012) stated that operational risks expose Islamic banks to potential investment deposits withdrawals, income loss, and contract cancelling. All the latter mentioned may affect Islamic banks' image and reputation, which may limit their future opportunities (Febianto, 2012). Consequently, each Islamic bank must complete a risk assessment to determine general classes of assets or investments, which can be considered appropriate for a given client. Risk capacity and risk tolerance are restrictions on potential investment returns. Since financial institutions are looking to receive recognition by all clients, their intentions essentially maximize clients' value and preferences in risk tolerance (Klement, 2018). Different theories presented in this paper will demonstrate a better understanding of clients' rationale or attitudinal behavior about the Islamic banks' sharing concept. The uniqueness aspects of Islamic banks are quite few; according to Hussain, Shahmoradi, and Turk (2015), the first is by making a profit through the principle of equity, which forbids predetermined payments and unwarranted uncertainty. Second is the principle of participation, which necessitates a borrower to give the bank $a$ share in their profits rather than paying interest. The principle of ownership forbids selling something one does not fully own (Hussain et al., 2015). However, Muslim and Christian clients alike accept that the poor, the orphans, and the needy have a prescribed or moral obligation to share in the earnings of assets. The latter mentioned may provide a healthier and safer society where the wealthy clients are inclined to share the risk that is anticipated in the poor's life. However, borrowers and depositors' competitive selection is not necessary to make the highest possible return, and not to be balanced against potential risk (Chowdhury, Saba, \& Habib, 2019). Moreover, in order to be balanced, the Islamic banks' method of conducting business needs to be understood.

\subsection{Related Theories}

Gawronski and Strack (2012) concluded that clients behave according to specified emotions or beliefs are known as attitudes. Islamic banks may refer to different theories to better align clients with their preferences. According to Gawronski and Strack (2012), the first theory is called cognitive dissonance, which uncovers a phenomenon where a client experiences distress due to conflicting thoughts, beliefs, or feelings between involved parties. Such inconsistency (dissonance) can be eliminated by taking specific steps (Gawronski \& Strack, 2012). Mainly, cognitive dissonance theory assumes a reevaluating attitude is comparable to what has been actually followed. Therefore, one way to overcome dissonance is by increasing the chosen alternative attractiveness (Festinger, 1964). Given the fact that dissonance is the feelings of clients, banks need to reevaluate it. In spite of the differences in what to signal, Islamic banks can manage their signals by relying on what creates clients' positive responses. 
Bizri (2014) and Alam et al. (2012) both assumed the possibility of building up a common belief among clients is important to enhance a condition for success. The religious factor is a major motive that can influence dissonance; in this regard, clients may absorb only information that affirms a pre-existing belief. Sometimes, new signals can be ignored if they contradict religious beliefs (Echchabi \& Aziz, 2012). Glanz, et al. (2015) considered perceived benefits as another influential factor. Also, Bananuka et al. (2019) defined perceived benefits as the degree of expected gratifications or consequences. One step ahead is to assume that Islamic banks' management may minimize dissonance by signaling one of its underlying best qualities. Connelly et al. (2011) and Senyonyi (2018) both considered one or more related signaling issues that may be selected from high corporate governance, transparency, trust, and accountability. Each of the latter mentioned is a critical lens of signaling theory (Lujja et al., 2018; Kaawaase \& Nalukwago, 2017). However, it is worth noting that a religious client is one suggested worthy signal.

Another theory that is worth mentioning is the transaction cost theory. It raises two opposing arguments about the impacts of cultural differences on bank selection. The first argument states that cultural distance is a function of differences in values rooted in personal emotions toward the costs and benefits. The second argument states that clients' difficulty to acquire accurate information (Chang et al., 1998). According to the transaction cost theory, each group of clients has their own risk or costbenefits; receiving and sacrificing something of approximately equal value will influence future relationships and feelings (Ltifi et al., 2016). Clients want to use one bank for a wide range of needs, and they want to do it in a way that fits their daily routine. A recent study suggested that bank clients still choose their banks primarily based on the lowest fees, close locations, and based on family or friends' recommendations, respectively. However, other beneficial factors may include bank reputation, interest rates, and existing relationships with the bank (Shelvin, 2018). Client value is the perception of what a product or service is worth to a client versus the possible alternatives. The latter means that clients feel the received benefits and services over what was paid. Microsoft Financial Services has outlined five top valued attributes of banks on the client's list, including easy banking, choices for how they bank, responsive customer service, and a better value of financial products and services (Microsoft, 2017). Ignoring the latter mentioned top values may negatively affect all banks, including Islamic banks, in maintaining clients.

\subsection{The Theory of Behavioral Finance}

Researchers published several studies that may challenge ideas about human nature adopted by conventional economics. Those researchers showed that choices are not always ideal, and human inclination to take risks is inclined by how decisions are presented (Samson, 2014). Such conclusion also applies in accounting and finance, which assumed that clients who deposit or borrow money are not always rational and have limited self-control and choices. Also, Delisi (2015) concluded that clients' ability to regulate once emotions and thoughts are subject to their motives and biases. In this regard, Markowitz established a deterministic model for optimal asset allocation. The latter mentioned model was under a highly unrealistic set of behavioral assumptions based on client's attitudes, beliefs, and experience (Antonides \& Van Der Sar, 1990). The deterministic model assumed that clients often ignore behavioral finance principles in their decision-making, and inefficient allocation of assets may affect clients' choice or selection (Humra, 2016). Some emotional expressions are composed of fear, confidence, anger, friendship, calmness, enmity, shame, pity, kindness, envy, indignation, emulation, and contempt (Karjaluoto et al., 2002). However, it is to say that clients are more likely to act efficiently in allocating their investments or selecting their bank over time based on a trade-off between expected gains versus losses. They prefer to take additional risks in order to achieve sufficient types of gains that neutralize the losses. It is essential to know that clients' choices are not fulfilled efficiently and not free from surrounded inefficiency components. Haselton et al. (2005) defined the latter mentioned as a part of cognitive biases or a systematic pattern of deviation from rationality in judgment. Due to clients' inability to solve a problem due to their available information-interpreting and limited experience, it can often be corrected through a banker's guidance.

\subsection{Signaling Theory and Clients Attitude}

Signaling theory supports and describes the behavior of banks as information senders. The sender chooses how or what to signal, and the receiver owns his way to interpret what has been sent to direct clienteles' choice (Kirmani, 1990). Banks are supposed to have less incentive to signal some things to others. For example, Ball and Shivakumar (2004) concluded that cases where banks were less enthused to signal others, such instances as shareholders turnover is high, and a directly close management monitoring with insider access to corporate information and low agency costs. Levie et al. (2008) indicated that insufficient disclosure or signals lead to wrong decisions and not easy to mitigate low performance. It is to say that banks hesitate to consider adequate and useful signal for making sound decisions is not good. Signaling theory has its own role in modifying the receiver's behavior closer to the sender's benefit. Signals may be honest, conveying information, usefully in increasing the goodness of the receiver. At the same time, a sender needs to avoid giving a dishonest signal. It becomes well known that both the sender and the receiver are exposed to the risk of undermining the signaling system. Fact versus false information is what the system needs to be built on. Additionally, Leventis et al. (2012) mentioned that since banks are risk accumulators, they seem to be hidden risks oriented. Banks' returns can be observed while risk cannot. Clients need to be smarter by not taking more risks and paying the same returns. It is allowed for them to play a game or decide a choice signaling in showing themselves taking higher 
risks and delivering the same return. Therefore, clients need to be smarter in understanding risk-return coefficient changes away from illusive signals. Clients' reaction depends on how their experience is, and their experiences depend on how they perceive banks incoming information.

\subsection{Client's Choice}

Several explanatory articles determine the most highlighted factors in the literature involving perceived quality of service, compliance with Islamic jurisprudence, and trust regarding the client's choice. Gerrard and Cunnigham (1997) examined the selection criteria for Islamic banking. The empirical results showed a general accord between Muslims and non-Muslims customers in terms of various criteria. A significant difference between Muslims and non-Muslims is being paid higher interest, which was far stronger with non-Muslims. In the same regard, In North Cyprus, it was found that the main factors that determine bank customers are efficiency level, service quality, parking facilities, image, emotional state, convention location, and financial aspects that may affect client opinion (Aga \& Safakli, 2007). In the same context, Chigamba and Fatoki (2011) claim that managers consider service quality a competitive advantage for financial institutions. Several organizations concentrate on revealing to their customer that they introduce better and more effective services than their competitors. However, Stafford (1996) suggested that quality can be employed to examine the differences between perceived service and clients' expectations. Additionally, the service quality and financial reputation are considered the main determinants of choosing Islamic banks in Malaysia (Dusuki \& Abdullah, 2007). However, customer selection factors can vary across countries. Kashif et al. (2015) argued that there is an insignificant relationship between reliability dimension and customers satisfaction with Malaysian Islamic banks. Al-Salim (2018) claims that bank employees' code of conduct is the main acknowledged aspect that affects customer satisfaction in the Jordanian banking sector. In fact, there might be a lack of confidence between the bank and customers unless there is a high possibility of sharing benefits between the bank and the customer (Gambetta, 2000). Trust is based on the perceived level of risk. Nasser et al. (1999) pointed out that trust is the main factor that may affect an Islamic bank's choice in Jordan. Other studies recommended that trust and reputation are significant to clients. Ahmad, Rustam, and Dent (2011) found that trust and brand reputation are key factors for choosing a bank. However, trust affect client future behavior (Gambetta, 2000). In the same regard, Maiyaki and Mokhtar (2011) found that bank size, number of branches, and reputation considered the key factors that affect banks' choice in Nigeria.

\subsection{Banking Service Excellence}

In more detail, providing exceptional service means to go above and beyond what clients expect to make them feel that the bank understands what they are going through. Providing employees, the tools they need to effectively do their job, thus providing generous self-service support and providing consistently accurate information across channels. Al-Khawaja and Bardai (2018) concluded that excellent services to achieve high confidence are required to retain clients. Excellency in this matter cannot be achieved in the short-term because it is a journey, not a destination; it is continuously raising the bar to improve the bank's current service performance. The latter is a commitment and a real challenge in seeking to strive for service excellence. The expected return level, which should be high enough to offset the costs of equity, is a must to attain clients; otherwise, no clients will deposit their money at a zero-return rate in a risky financial institution (García-Herrero et al., 2009). Islamic banks finance their assets at increasing expected profitability to offset the cost of equity is not a matter of choice. Signaling theory assumes that bank management signals private information about a positive relationship between Islamic banks' prospects to increase equity return. Alshurideh et al. (2017) specified that after a set of service quality dimensions, the two researchers concluded that tangibility, reliability, empathy, assurance, and responsiveness significantly impact choice. Additionally, clients expressed high levels of loyalty towards all service quality dimensions to better understand each service essential antecedents and consequences (Alshurideh et al., 2017). Additionally, the previously mentioned research concluded that established methods for improving such quality to exert better care for loyal clients between them are the most profitable to them.

\section{Methodology}

The study is conducted utilizing a previously used survey of 150 and was sent to sample Islamic bank clients randomly selected across Islamic banks in Jordan. However, only 138 were returned filled out. The internal consistency and reliability of the survey instrument were assessed using Cronbach's Alpha. Also, for data analysis, descriptive tools and t-test were conducted. The research respondents specified their level of agreement on five levels Likert scale, as shown below. The levels of agreements were classified as the following:

$$
\text { A - Low degree of agreement ( } 1 \text { to 2.33) B - The medium degree of agreement (2.34 to C - A high degree of agreement (3.68 to 5) }
$$

\subsection{Hypotheses}

Hypothesis $\mathrm{H}_{1}$ : The Religious factors signaled by an Islamic bank have a statistically significant influence on the clients' choice decision.

Hypothesis $\mathrm{H}_{2}$ : The non-religious factors signaled by an Islamic bank significantly influence the clients' choice decision. 


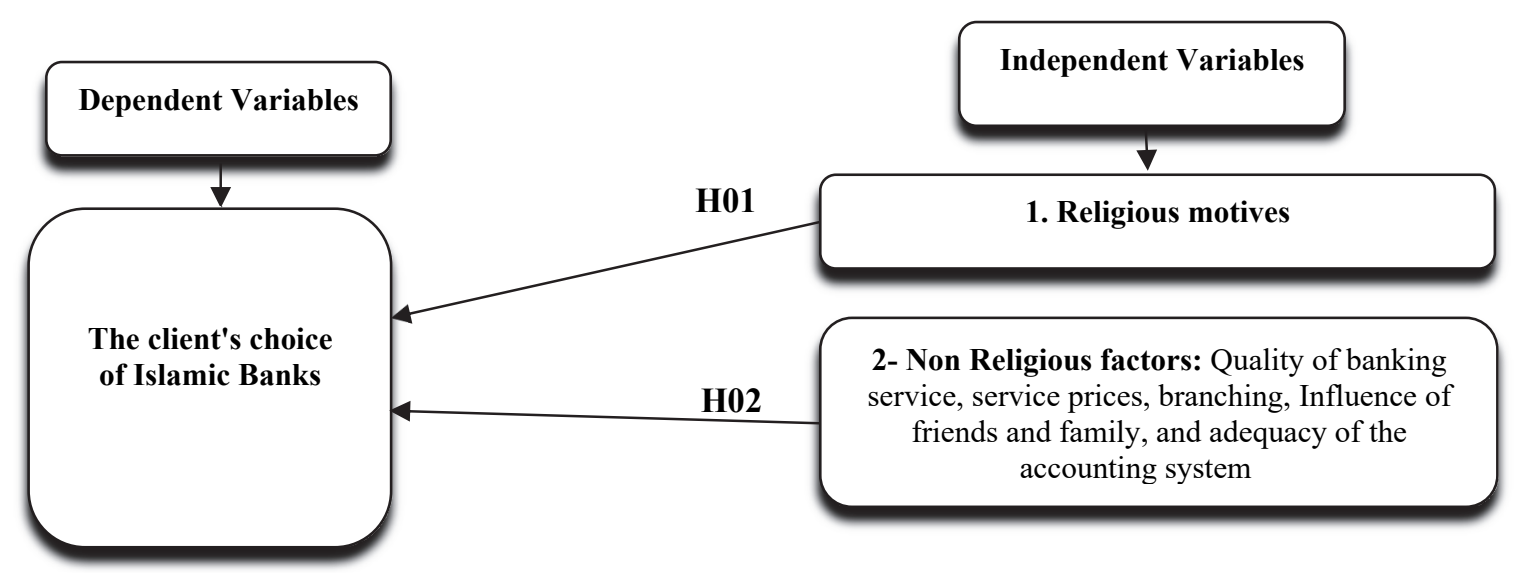

\section{Findings and Discussions}

Fig. 1. The study model

\subsection{Data Presentation}

The study covered three participant banks operating in Jordan while keeping their names anonymous, the questionnaires were distributed inside the city of Amman branches, and face-to-face surveys were conducted. The questionnaire was divided into two main parts; section one contained demographic information - section two specified clients' attitudes toward banking issues. In the second part, participants were requested to rate the relative importance of banks selection criteria on a five-point Likert scale ranging from important to not important. The instrument for the study was adopted from previous literature (Al-Ajmi et al., 2009).

\subsection{Demographic Information}

In the first part, the survey included demographic information showing participants' descriptive elements such as occupations, age, academic level, and monthly income. In more detail, Fig. 1 shows that $(8.7 \%)$ of the clients are working in the private sector and $91.30 \%$ in the public sector. $(58.26 \%)$ are below 30 years of age and $(41.74 \%)$ above that. Only $(38.3 \%)$ of them are not holding a university degree, and $(61.70 \%)$ have a bachelor's degree or above. The average monthly income is mostly below JD1,000, equivalent to \$1,400 US Dollars per month.

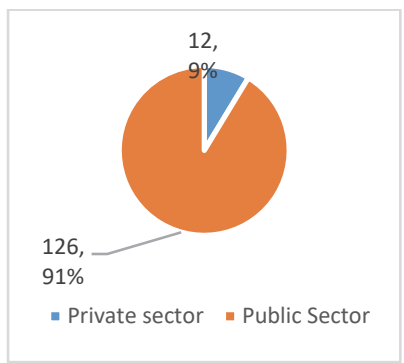

Occupation

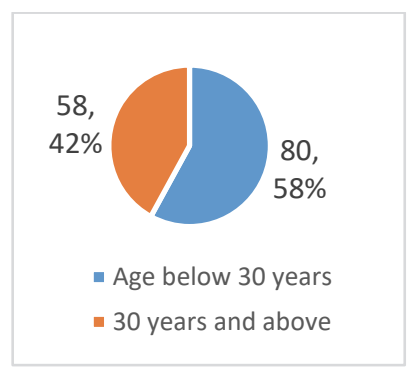

Age

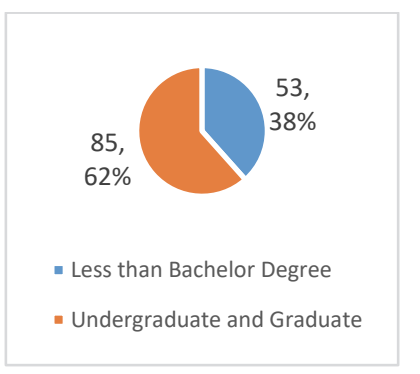

Academic Level

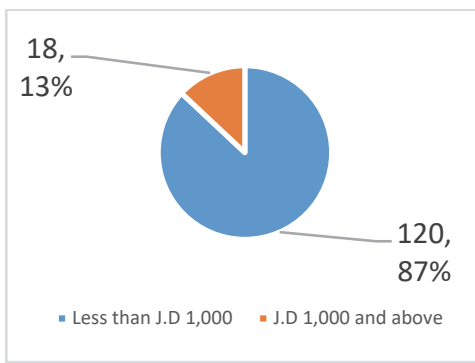

Monthly Income

\subsection{Religion-related factors}

Fig. 1. Demographic information

Table 1 shows statements fulfilling the first section of this paper second part, the religion factor motive on client's choice. Descriptive statistics of the collected data shows the agreement arithmetic means ranged between (2.54 to 3.03) and the grand mean of 2.83. The highest arithmetic mean was (3.03), with a standard deviation of (0.80) was on statement 5; this relatively low standard deviation reflects a common agreement between respondents. It was about how 138 respondents believed in the need for a religious edict to justify Islamic banks' service. However, the edict term of statement number 5 is to ensure religious freedom in protecting peoples' rights to live, speak, and act according to their beliefs. It is the statement graded by the level of high mean. The most prominent elements in other statements are Islam's alignment principles by the clients at the medium level. The medium level arithmetic mean was depicted by eight statements in table $2(1,2,3,4,5,6,7,8)$. All are ensuring that participants are pro-Islamic banks due to the contents of such statements. The grand mean of this section is at the medium level of 2.83 out of 5 . The 9 Statements of Table 2 are covering beliefs on the interest rate and other prohibited banking financial issues not acceptable by respondents. 
Table 1

Religious motives for the clients' choice

\begin{tabular}{|c|c|c|c|c|c|}
\hline No. & Statement & $\begin{array}{c}\text { Arithmetic } \\
\text { mean }\end{array}$ & $\begin{array}{l}\text { Standard } \\
\text { deviation }\end{array}$ & t- test & Status \\
\hline 1 & The services I got from Islamic banks are in line with my religious principles. & 2.54 & 0.86 & 4.06 & Medium \\
\hline 2 & What encourages me to deal with Islamic banks is the absence of interest. & 2.83 & 0.97 & 4.65 & Medium \\
\hline 3 & I see that the Islamic banking system is in line with the principles of Islam. & 2.95 & 0.90 & 4.74 & Medium \\
\hline 4 & I would like to compare between religious standards and what is offered by Islamic banks. & 2.98 & 1.24 & 4.80 & Medium \\
\hline 5 & A religious edict is to justify any service offered by the Islamic banks & 3.03 & 0.80 & 4.93 & High \\
\hline 6 & Non-Muslims find substantial benefits through their dealings with Islamic banks. & 2.59 & 0.84 & 4.11 & Medium \\
\hline 7 & The principle of profit-sharing is the best alternative, in replacing the principle of interest rates. & 2.93 & 0.82 & 4.71 & Medium \\
\hline 8 & I admit religion standard when dealing with Islamic banks & 2.83 & 0.86 & 4.61 & Medium \\
\hline \multirow[t]{2}{*}{9} & Suitable and Islamic price basis of banking services. & 2.77 & 0.86 & 4.58 & Medium \\
\hline & Grand Mean & 2.83 & 0.91 & 4.58 & Medium \\
\hline
\end{tabular}

Each accepted statement was based on the Islamic slogan, such as all activities taken by Islamic banks should be free of excessive uncertainty and various forms of admitted policies. Implicitly, such statements include the bank not investing in companies involved with alcoholic beverages, gambling, non-Islamic financial services, pornography, and tobacco or weapons. As an internal control system, Islamic financial institutions work under a supervisory board composed of executive management and Islamic scholars whose role is to ensure that their banking activities are undertaken according to Islamic standards. Respondents level out of Likert high score, less than number five seems to allow for a room of disagreement in all Table 1 statements. The latter means that clients are expecting something else, improvements to religious issues.

\subsection{Non-religion related factors}

Table 2 shows the arithmetic means of statements related to non-religious motives. Clients' answers were ranged between (2.362.81 ), at medium level. Statement number 8 was on the accounting information system disclosing the client's needs. It has the highest arithmetic mean of (2.81) out of five and (0.82) standard deviation. The lowest mean was (2.36) on statement 3 of attractive branches' appearance, and all statements are at a medium acceptance level.

\section{Table 2}

Non -religious motive

\begin{tabular}{|c|c|c|c|c|c|}
\hline No. & Statement & $\begin{array}{c}\text { Arithmetic } \\
\text { mean }\end{array}$ & $\begin{array}{l}\text { Standard } \\
\text { deviation }\end{array}$ & t- test & Status \\
\hline 1 & Choosing Islamic banks is due to their sufficient branches. & 2.46 & 0.78 & 4.02 & Medium \\
\hline 2 & Choosing Islamic banks is due to caring and comfortable. & 2.55 & 0.75 & 4.05 & Medium \\
\hline 3 & Choosing Islamic banks is because of their appearance and internal decoration design & 2.36 & 0.75 & 3.92 & Medium \\
\hline 4 & Choosing Islamic banks is due to their fast services to clients. & 2.60 & 0.80 & 4.36 & Medium \\
\hline 5 & Choosing Islamic banks is because of their instant response to the needs of their clients. & 2.52 & 0.80 & 4.41 & Medium \\
\hline 6 & Choosing Islamic banks is because of the sufficient number of staff. & 2.44 & 0.81 & 4.12 & Medium \\
\hline 7 & Choosing banks is due to giving clients the top priorities. & 2.68 & 0.76 & 4.72 & Medium \\
\hline 8 & Choosing banks is due to the availability of information system disclosing my need. & 2.81 & 0.82 & 4.62 & Medium \\
\hline 9 & Choosing banks is due to sufficient attention to every client. & 2.57 & 0.80 & 4.42 & Medium \\
\hline 10 & Choosing Islamic bank is due to the competitive service prices. & 2.59 & 0.66 & 4.32 & Medium \\
\hline \multirow[t]{2}{*}{11} & Choosing Islamic bank is due to the influence of friends and family. & 2.68 & 0.73 & 4.80 & Medium \\
\hline & Grand Mean & 2.57 & 0.77 & 4.34 & Medium \\
\hline
\end{tabular}

However, table 2 shows levels of attracting clients' attention on 11 statements. The banks can detect, monitor, and identify clients' needs as an essential task. Each statement focuses on non-religious factors such as personal care, branching, services prices, accounting system, clients' attention, and fast response to the client's needs. In general, banks nowadays are improving their services and upgrading their qualities by identifying the clients' preferences and expectations. Banks' attempts are to increase sales in the long run due to attracting clients and retaining them. A successful and profitable bank is that one sets its priorities right. Clients' needs should always be the first priority and the ultimate goal for increasing sales. Good client's service is directly proportional to the number of clients, which eventually contributes to higher sales. The previous 11 statements are significant ways to achieve service excellence, increase good customer care, and generate profit by increasing sales. They draw client attention and encourage them to come back for further services to extend the relationship.

\subsection{Hypotheses Testing}

Hypothesis $\mathrm{H}_{1}$ : The one-sample t-test at the tabulated value of 2.33 with significance at the 0.01 level has been applied to accept or reject the 11 statements of hypothesis one included in Table 2. The calculated t was 4.58, which makes it possible to confirm the null hypothesis, which states that "The Religious factors signaled by an Islamic bank have a statistically significant influence on the clients' choice decision". Therefore, it indicates the presence of a positive relationship between religious factors and Islamic banks clients' choice. It is also confirmed that each statement in the table reflects a sub of hypothesis one, which proved a positive and significant relationship on clients' choice. 
Hypothesis $\mathrm{H}_{2}$ : The one-sample t-test at the tabulated value of 2.33 with significance at the 0.01 level has been applied to accept or reject the nine statements of hypothesis two included in Table 2. The value of t was 4.34 makes it possible to accept the null hypothesis, which states that "The non-religious factors signaled by an Islamic bank significantly influence the clients' choice decision". Therefore, it indicates that there is a positive relationship between non-religious factors and Islamic banks clients' choice. It is also confirmed that each statement in the table reflects a sub of hypothesis two, which demonstrated a positive and significant relationship on clients' choice.

\section{Conclusion, Limitation, and Study Forward}

This study has concluded that the attitude formation of clients' selection criteria shows that the non-religious product and service features are highly regarded. It also suggests that clients' religious-related issues are highly assumed, but it is not the sole reason to select an Islamic bank. The management of Islamic banks needs to consider product features and service quality as equally important to Islamic standards in designing the strategy of Islamic banking selection criteria. Both religious and non-religious factors are similarly important in signaling the clients and building-up their expectations and attitudes. It is not possible to say that religious factors are enough to determine the dimensions of choosing banks. Still, the non-religious or the economic factors are broadly represented by the interest-free banking and profit-sharing principles are so important to build up a positive attitude towards Islamic banks. The research findings indicate that both religious and non-religious values can significantly impact clients' intentions and choices. It suggests that religious edict is an essential factor. Among non-religious is the availability of an information system disclosing clients' needs. This paper supports the fact that Islamic banks are in need of attracting and retaining clients. To retain clients, Islamic banks would have to develop relevant strategies designed to meet such requirements. Non-religious factors as the sole motivation for choosing Islamic banks have been enlarged by constricting many related theories. The latter is expected to broaden Islamic banks' scope in developing strategies toward clients' attitude formation.

\section{References}

Aga, M., \& Safakli, O. V. (2007, January). An empirical investigation of service quality and customer satisfaction in professional accounting firms:Evidence from North Cyprus . Problems and Perspectives in Management, 5(3), 84-97.

Ahmad, K., Rustam, G. A., \& Dent, M. M. (2011). Brand preference in Islamic banking. Journal of Islamic Marketing, $2(1), 74-82$.

Alam, S., Janor, H., Jano, Z., Che Wel, C. A., \& Ahsan, M. N. (2012, January 1). Is religiosity an important factor in influencing the intention to undertake Islamic home financing in Klang Valley? World Applied Sciences Journal, 19, 1030-1041.

Aliouat, B., Moez, L., Hikkerova, L., \& Gharbi, J. (2016, June 1). The determinants of the choice of Islamic banks in Tunisia. International Journal of Bank Marketing, 34(5), 710-730.

Al-Khawaja, H. A., \& Bardai, B. (2018, March 27). Standard quality banking services of Islamic banks. Journal of Public Administration and Governance, 8(1), 301-316.

Al-Salim, M. A. (2018, July 3). A closer look at the relationship of entry-level bank employees' leadership attributes and customer satisfaction. Journal of Financial Services Marketing, 23(5), 91-103.

Alshurideh, M. T., Ibraheem Shelash Al-Hawary, S. I., Mohammad, A. M., Mohammad, A. A., \& Al Kurdi, B. H. (2017, April 1). The impact of Islamic banks' service quality perception on Jordanian customers loyalty. Journal of Management Research, 9(2), 139-159.

Antonides, G., \& Van Der Sar, N. L. (1990, June). Individual expectations, risk perception and preferences in relation to investment decision making. Journal of Economic Psychology, 11(2), 227-245.

Ball, R., \& Shivakumar, L. (2004, April 14). Earnings quality in UK private firms: Comparative loss recognition timeless. Journal of Accounting and Economics, 39, 83-128.

Bananuka, J., Kaawaase, T. K., Kasera, M., \& Nalukenge, I. (2019). Determinants of the intention to adopt Islamic banking in anon-Islamic developing country: The case of Uganda. ISRA International Journal of Islamic Finance, 11(2), 166-186.

Bizri, R. (2013, January 1). A study of Islamic banks in the non-GCC MENA region: Evidence from Lebanon. International Journal of Bank Marketing, 32.

Chang, M. K. (1998, December 1). Predicting unethical behavior: A comparison of a theory of reasoned action and the theory of planned behavior. Journal of Business Ethics, 17, 1825-1834.

Chigamba, C., \& Fatoki, O. (2011). Factors influencing the choice of commercial banks by university students in South Africa. International Journal of Business and Management, 6(6), 66-76.

Chowdhury, Y., Saba, N., \& Habib, M. (2019, January 10). Factors affecting the choice of Islamic banking by the customers: A case study. Frontiers in Management Research, 3.

Connelly, B., Certo, T., Ireland, R., \& Reutzel, C. (2011, January 1). Signaling theory: A review and assessment. Journal of Management, $37,39-67$.

Delisi, M. (2015). Low self-control is a brain-based disorder. In K. M. Beaver, J. C. Barnes, \& B. B. Boutwell (Eds.), The Nurture Versus Biosocial Debate in Criminology (1st ed., pp. 172-182). https://doi.org/10.4135/9781483349114.n11

Dusuki, A. W., \& Abdullah, I. (2007, April). Why do Malaysian customers patronise Islamic banks? International Journal of Bank Marketing, 25(3), 142-160. https://doi.org/10.1108/02652320710739850

Echchabi, A., \& Aziz, H. A. (2012). Empirical investigation of customers' perception and adoption towards Islamic banking services in Morocco. Middle-East Journal of Scientific Research, 12(6), 849-858.

Febianto, I. (2012). Adapting risk management for profit and loss sharing financing of Islamic banks. Scientific Research, 3(1), 73-80.

Festinger, L. (1964). Conflict, decision, and dissonance. Redwood City, California: Stanford U. Press.

Festinger, L., \& Carlsmith, J. M. (1959). Cognitive consequences of forced compliance. The Journal of Abnormal and Social Psychology, 58(2), 203. 
Gambetta, D. (2000). Can We Trust Trust? In Trust: Making and breaking cooperative relations (pp. 213-237). Retrieved from http://www.sociology.ox.ac.uk/papers/gambetta213-237.pdf

Gawronski, B., \& Strack, F. (2012). Cognitive consistency: A fundamental principle in social cognition. New York, New York: Guilford Press.

Gerrard, P., \& Cunningham, B. (1997, November). Islamic banking: A study in Singapore. International Journal of Bank Marketing, 15(6), 204-216. https://doi.org/10.1108/02652329710184433

Glanz, K., Rimer, B. K., \& Viswanath, K. (2015). Health behavior: Theory, research, and practice (5th ed.). Hoboken, NJ: Jossey-Bass and Wiley.

Groening, C., Yildirim, P., Mittal, V., \& Tadikamalla, P. (2014). Hedging customer risk. Springer Science+Business Media, 1, $105-116$.

Hamza, H. (2016). Does investment deposit return in Islamic banks reflect PLS principle? Borsa Istanbul Review, 16(1), 32-42.

Haselton, M. G., Nettle, D., \& Andrews, P. W. (2015). The evolution of cognitive bias. Hoboken, NJ: John Wiley and Sons Inc.

Herrero, A., \& Sergio Gavilá, S. (2018, March 26). What explains the low profitability of Chinese banks? The BBVA Economic Research Department.

Heskett, J. L., Sasser Jr., W. E., \& Hart, C. W. (1990). Service breakthroughs: Changing the rules of the game. New York, New York: The Free Press.

Humra, Y. (2016, February/March). Behavioral finance: An introduction to the principles governing investor behavior in stock markets. International Journal of Financial Management, 5(2), 23-30.

Hussain, M., Shahmoradi, A., \& Turk, R. (2016). An overview of Islamic finance. Journal of International Commerce, Economics and Policy, $7(01), 1650003$.

Jasim Al-Ajmi, J., Abo Hussain, H., \& Al-Saleh, N. (2009, September 25). Clients of conventional and Islamic banks in Bahrain: How they choose which bank to patronize. International Journal of Social Economics, 36(11), 1086-1112.

Kaawaase, T., \& Nalukwago, L. (2017, May 26). Religiosity and Islamic banking in Uganda. Makerere Business Journal, $13,70-93$.

Karjaluoto, H., Mattila, M., \& Pento, T. (2002, November 1). Factors underlying attitude formation towards online banking in Finland. International Journal of Bank Marketing, 20(6), 261-272.

Katircioglu, S. T., Tumer, M., \& Ceyhun Kılınç, C. (2011, July). Bank selection criteria in the banking industry: An empirical investigation from customers in Romanian cities. African Journal of Business Management, 5(14), 5551-5558.

Kirmani, A. (1990). The effect of perceived costs on brand perceptions. Journal of Consumer Research, 17, $160-171$.

Klement, J. (2018, June). Risk profiling and tolerance: Insights for the private wealth manager. CFA Institute Research Foundation Publications. https://doi.org/10.2139/ssrn.3247803

Leventis, S., Dimitropoulos, P., \& Anandarajan, A. (2012, September 21). Signalling by banks using loan loss provisions: The case of the European Union. Journal of Economic Studies, 39, 604-618.

Levie, J., Majid, I., Cooper, S., \& Ismail, K. (2008). Entrepreneurial management and technology-based firm performance. International Journal of Advanced Manufacturing Technology, 2, 79-98.

Lujja, S., Mohammed, M., \& Hassan, R. (2018, March 21). Islamic banking: An exploratory study of public perception in Uganda. Journal of Islamic Accounting and Business Research, 9(3), 336-352.

Maiyaki, A. A., \& Mokhtar, S. S. (2011, January). Determinants of customer behavioural responses: A pilot study . International Business Research, 4(1), 193-197.

Microsoft. (2017). The top five things a customer needs from their bank. Retrieved from https://cloudblogs.microsoft.com/industryblog/financial-services/2017/12/07/the-top-five-things-a-customer-needs-from-their-bank/

N'Goala, G. (2007, October 16). Customer switching resistance (CSR): The effects of perceived equity, trust and relationship commitment. International Journal of Service Industry Management, 18, 510-533.

Reichheld, F. F., \& Sasser, Jr., W. E. (1990, September/October). Zero defections: Quality comes to services. Harvard Business Review, 68(5), $105-111$.

Samson, A. (2014). An introduction to behavioral economics. Behavioraleconomics.com. Retrieved from https://www.behavioraleconomics.com/resources/introduction-behavioral-economics/

Selnes, F. (2011, May). Commentaries and rejoinder to balancing risk and return in a customer portfolio. Journal of Marketing, 75(3), 18-21. Retrieved from www.jstor.org/stable/41228592

Senyonyi, T. W. (2018, February 21). Islamic banking: Can it succeed in Christian dominant Uganda? Business Focus: Money Matters Simplified. Retrieved from https://businessfocus.co.ug/islamic-banking-can-succeed-christian-dominant-uganda/

Shelvin, R. (2018). How consumers choose A bank: A tale of two surveys. Retrieved from https://www.crnrstone.com/insightvault/2018/08/23/how-consumers-choose-a-bank-a-tale-of-two-surveys/

Stafford, M. R. (1996, August 1). Demographic discriminators of service quality in the banking industry. Journal of Services Marketing, 10(4), 6-22.

Stuart, F. I., McCutcheon, D. M., Handfield, R., McLaughlin, R., \& Sampson, D. (2002). Conducting successful case research: A process perspective. Journal of Operations Management, 20(5), 419-433.

Wilson, A. M., Zeithaml, V. A., Bitner, M. J., \& Gremler, D. (2008). Services Marketing (1st ed.). New Delhi, India: McGraw-Hill Education. Yau, O. H. (1994). Consumer behavior in China: Customer satisfaction and cultural values. New York, New York: Routledge.

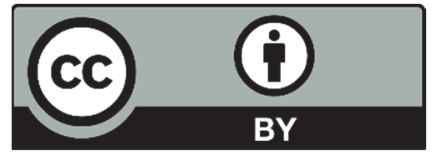

(C) 2021 by the authors; licensee Growing Science, Canada. This is an open access article distributed under the terms and conditions of the Creative Commons Attribution (CC-BY) license (http://creativecommons.org/licenses/by/4.0/). 